\title{
In vitro Accelerated Aging of Composites and a Sealant
}

J. M. POWERS, P.L. FAN, and M. MARCOTTE

School of Dentistry, University of Michigan, Ann Arbor, Michigan 48109

The in vitro accelerated aging of conventional and microfilled composite restorative materials and a sealant was studied. Volume loss/surface area ranged from 2.0 to $7.3 \times 10^{-3} \mathrm{~mm}^{3} / \mathrm{mm}^{2}$ after $900 \mathrm{~h}$ of aging. Surface morphology changed more dramatically for the conventional composites than for the other materials. Changes in surface chemistry as measured by FTIR-ATR were observed.

J Dent Res 60(9):1672-1677, September 1981

\section{Introduction.}

Surface degradation of composite restorative materials has been studied in vitro by accelerated aging in a weathering chamber. ${ }^{1}$ Aging for $900 \mathrm{~h}$ caused erosion of the resin matrices and exposure of filler particles. Crazing of the resin matrices was similar to that reported in vivo by O'Brien and Yeh. ${ }^{2}$ Differences in surface profiles of the aged composites suggested that the materials eroded at different rates.

The purpose of this study was to evaluate weight loss, volume loss, and changes in surface chemistry and morphology of conventional and microfilled composites and a sealant after accelerated aging in vitro.

\section{Materials and methods.}

The in vitro accelerated aging of eight commercial composite restorative materials and a pit and fissure sealant was evaluated.

Received for publication June 3, 1980

Accepted for publication November 6, 1980

This investigation was supported in whole by U.S.P.H.S. Research Grant DE-03416 from the National Institute of Dental Research, National Institutes of Health, Bethesda, MD 20205.

This investigation was presented at the annual meeting of the International Association for Dental Research in Osaka, Japan, June, 1980.

The cooperation of the following companies in providing commercial products is acknowledged: Johnson \& Johnson; 3M Co.; Kerr Manufacturing Co.; Phasealloy, Inc.; Vivadent (USA), Inc.; and S.S. White.

The infrared spectra were run by Digilab, Inc., as a courtesy.
The code, shade, batch number, and manufacturer are listed in Table 1 for each of five conventional composites (A, AR, C, $P R$, and $S$ ), three microfilled composites (I, PF, and SF), and a sealant (D).

Five samples $(20 \mathrm{~mm}$ diameter and $1 \mathrm{~mm}$ thick) were prepared for each material by polymerization in a die. The samples were placed in an oven at $37^{\circ} \mathrm{C}$ within $90 \mathrm{~s}$ after initiating the mix and were stored for $24 \mathrm{~h}$ before drying to a constant weight over freshly regenerated silica gel in a desiccator. The balance* was accurate to $0.1 \mathrm{mg}$.

The samples were exposed to conditions of accelerated aging for $900 \mathrm{~h}$ in a weathering chamber ${ }^{\dagger}$ at $43^{\circ} \mathrm{C}$ and $90 \%$ relative humidity. One surface of each sample was subjected continuously to the radiation of a 2500 watt light source filtered by borosilicate glass and to an intermittent water spray for $18 \mathrm{~min}$ every two $\mathrm{h}$. The intensity of the uv radiation was measured with a uv meter $\S$ to be about $11.2 \mathrm{mWatts} / \mathrm{cm}^{2}$ at the sample position. After aging the samples were dried again to constant weight. The change in weight caused by aging was calculated and used to determine volume loss. Density was determined on one new sample of each material by a water displacement technique. The exposed surface area of a sample was calculated by geometry to be $377 \mathrm{~mm}^{2}$.

Surface morphology of the materials was observed after $900 \mathrm{~h}$ of aging by scanning electron microscopy." Changes in the surface chemistry of AR and SF were studied by Fourier transform infrared spectroscopy

*Model H 14, Mettler Instrument Corp., Princeton, NJ 08540

†Weather-Ometer 25-WR, Atlas Electric Devices Co., Chicago, IL 60613

\$12-2881 Xenon Burner, Atlas Electric Devices Co., Chicago, IL 60613

§ Model J-221, Ultraviolet Products, Inc., San Gabriel, CA 91778 Japan

"JSM-U3, Japan Electron Optics Laboratory, 
TABLE 1

CODE, NAME, BATCH NUMBERS, and MANUFACTURER OF PRODUCTS TESTED

\begin{tabular}{|c|c|c|c|c|}
\hline \multirow{2}{*}{$\frac{\text { Code }}{\text { Conventional Composites: }}$} & \multirow{2}{*}{\begin{tabular}{l}
\multicolumn{1}{c}{$\begin{array}{c}\text { Product Name } \\
\text { (Shade) }\end{array}$} \\
$\begin{array}{l}\text { Adaptic } \\
\text { (Universal) }\end{array}$
\end{tabular}} & \multicolumn{2}{|c|}{$\begin{array}{l}\text { Batch } \\
\text { Numbers }\end{array}$} & \multirow{2}{*}{\begin{tabular}{l}
\multicolumn{1}{c}{ Manufacturer } \\
Johnson \& Johnson \\
Dental Products Division \\
East Windsor, NJ 08520
\end{tabular}} \\
\hline & & $\begin{array}{l}\text { base } \\
\text { catalyst }\end{array}$ & $\begin{array}{l}-8 C 004 \\
-8 C 004\end{array}$ & \\
\hline $\mathrm{AR}$ & $\begin{array}{l}\text { Adaptic Radiopaque } \\
\text { (Universal) }\end{array}$ & $\begin{array}{l}\text { base } \\
\text { catalyst }\end{array}$ & $\begin{array}{l}-8 \mathrm{H} 109 \\
-8 \mathrm{H} 109\end{array}$ & Johnson \& Johnson \\
\hline $\mathrm{C}$ & $\begin{array}{l}\text { Concise } \\
\text { (Universal) }\end{array}$ & $\begin{array}{l}\text { paste } A \\
\text { paste } B\end{array}$ & $\begin{array}{l}-8023 \\
-8 L 23\end{array}$ & $\begin{array}{l}\text { 3M Company } \\
\text { St. Paul, MN 55101 }\end{array}$ \\
\hline PR & $\begin{array}{l}\text { Profile } \\
\text { (Shade 55) }\end{array}$ & $\begin{array}{l}\text { base } \\
\text { catalyst }\end{array}$ & $\begin{array}{l}-47812 \\
-37901\end{array}$ & $\begin{array}{l}\text { S.S. White, Div. of Pennwalt } \\
\text { Philadelphia, PA } 19102\end{array}$ \\
\hline$s$ & $\begin{array}{l}\text { Simulate } \\
\text { (Universal) }\end{array}$ & $\begin{array}{l}\text { base } \\
\text { catalyst }\end{array}$ & $\begin{array}{l}-91037 \\
-92044\end{array}$ & $\begin{array}{l}\text { Kerr Manufacturing Co. } \\
\text { Div. of Sybron Corp. } \\
\text { Romulus, MI } 48174\end{array}$ \\
\hline $\begin{array}{l}\text { Microfilled Composites: } \\
\text { I }\end{array}$ & $\begin{array}{l}\text { Isopast } \\
\text { (Shade 22) }\end{array}$ & $\begin{array}{l}\text { base } \\
\text { catalyst }\end{array}$ & $\begin{array}{l}-721078 \\
-630179\end{array}$ & $\begin{array}{l}\text { Vivadent (USA), Inc. } \\
\text { Buffalo, NY } 14214\end{array}$ \\
\hline PF & $\begin{array}{l}\text { Phaseafill } \\
\text { (Shade GO) }\end{array}$ & $\begin{array}{l}\text { base } \\
\text { catalyst }\end{array}$ & $\begin{array}{l}-026 \\
-044\end{array}$ & $\begin{array}{l}\text { Phasealloy, Inc. } \\
\text { E1 Cajon, CA } 92021\end{array}$ \\
\hline SF & $\begin{array}{l}\text { Superfil } \\
\text { (Universal) }\end{array}$ & $\begin{array}{l}\text { universal } \\
\text { catalyst }\end{array}$ & $\begin{array}{l}-80338 \\
-80329\end{array}$ & $\begin{array}{l}\text { Harry J. Bosworth Co. } \\
\text { Skokie, IL } 60076\end{array}$ \\
\hline $\begin{array}{l}\text { Sealant: } \\
\text { D }\end{array}$ & Delton & $\begin{array}{l}\text { universal } \\
\text { catalyst }\end{array}$ & $\begin{array}{l}-5001 \\
2792 \mathrm{EA} \\
-5001 \\
2792 \mathrm{DA}\end{array}$ & Johnson \& Johnson \\
\hline
\end{tabular}

TABLE 2

PARAMETERS DESCRIBING AGING OF CONVENTIONAL AND MICROFILLED COMPOSITES AND A SEALANT

\begin{tabular}{llcc}
\hline \multicolumn{1}{c}{ Code } & $\begin{array}{c}\text { Weight Loss/ } \\
\text { Surface Area, } \\
\mathrm{mg} / \mathrm{cm}^{2}\end{array}$ & $\begin{array}{c}\text { Density } \\
\mathrm{g} / \mathrm{cm}^{3}\end{array}$ & $\begin{array}{c}\text { Volume Loss/ } \\
\text { Surface Area, } \\
10^{-3} \mathrm{~mm}^{3} / \mathrm{mm}^{2}\end{array}$ \\
$\begin{array}{l}\text { Conventional } \\
\text { Composites: }\end{array}$ & & & \\
$\quad$ A & $1.16(0.06)^{*}$ & 1.960 & $5.9(0.3)^{\dagger}$ \\
AR & $0.70(0.11)$ & 1.982 & $3.6(0.6)$ \\
C & $1.09(0.10)$ & 2.098 & $2.1(0.5)$ \\
PR & $0.46(0.10)$ & 2.112 & $5.1(1.4)$ \\
S & $1.03(1.29)$ & 2.046 & \\
Microfilled & & & $2.0(0.7)$ \\
Composites: & & 1.392 & $3.5(0.6)$ \\
I & $0.28(0.10)$ & 1.462 & $7.3(1.6)$ \\
PF & $0.51(0.08)$ & 1.407 & $3.9(0.4)$ \\
SF & $1.03(0.21)$ & & \\
Sealant: & & 1.188 & \\
D & $0.46(0.04)$ & & \\
\hline
\end{tabular}

* Mean value of five replications with standard deviations in parentheses. The Tukey interval at the $95 \%$ level of confidence was $0.26 \mathrm{mg} / \mathrm{cm}^{2}$.

$\dagger$ The Tukey interval at the $95 \%$ level of confidence was $1.5 \times 10^{-3} \mathrm{~mm}^{3} / \mathrm{mm}^{2}$. 
(FTIR) ${ }^{\#}$ in an attenuated total reflectance (ATR) mode using a thallium bromideiodide crystal (KSR-5). Reflectance spectra were obtained at zero and $900 \mathrm{~h}$ for a representative sample of $\mathrm{AR}$ and $\mathrm{SF}$ between

\#Model FTS-20C/D, Digilab, Inc., Cambridge, MA 02139
400 and $4000 \mathrm{~cm}^{-1}$. Difference spectra were obtained by subtraction of 900 -hour from zero-hour spectral data using a computer program. The spectra were factored to cancel sharp $\mathrm{C}-\mathrm{H}$ peaks in the subtraction. The resolution of the spectrophotometer was $0.08 \mathrm{~cm}^{-1}$.

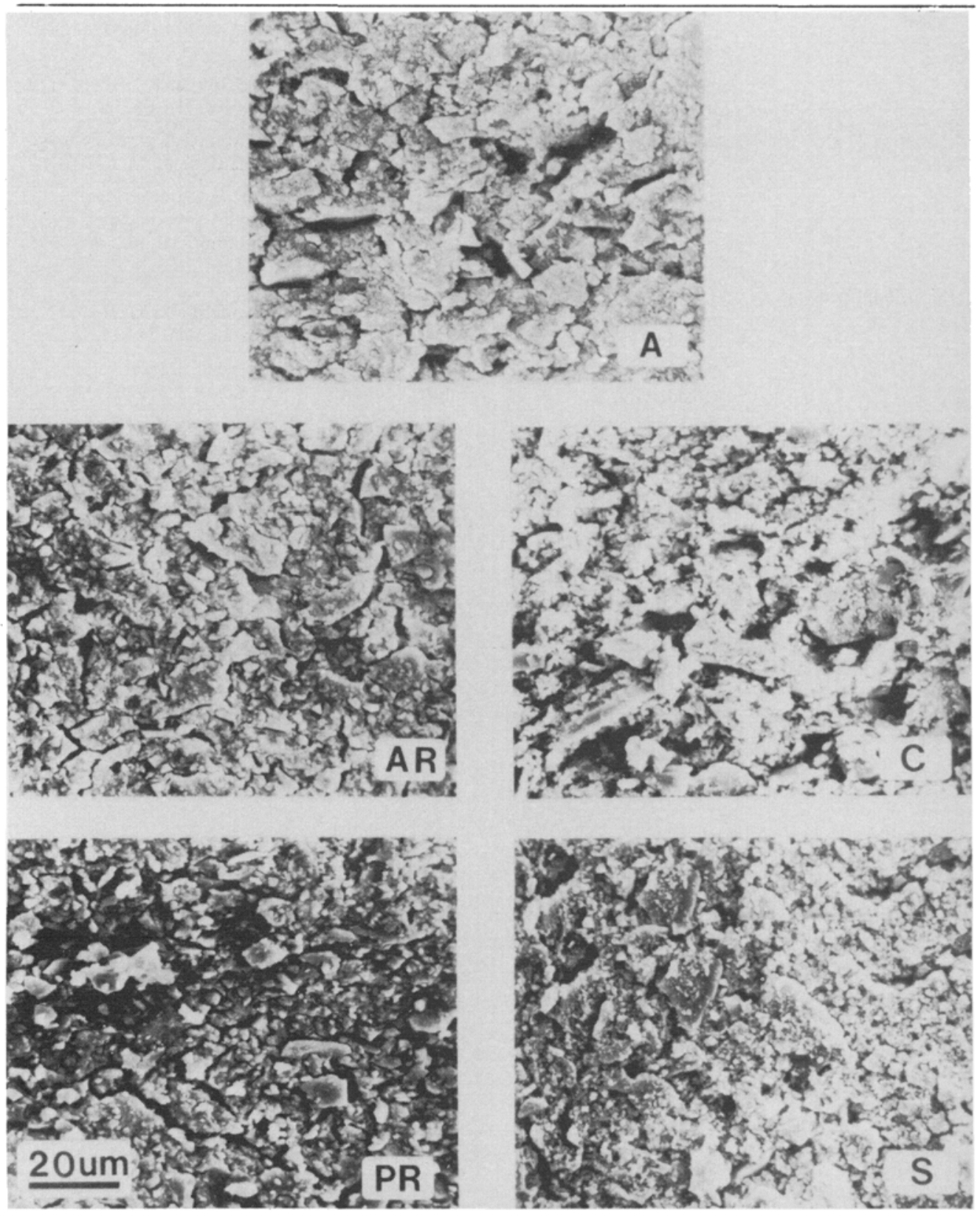

Fig. 1 - Scanning electron photomicrographs of aged surfaces of conventional composites. 


\section{Results.}

Parameters describing the aging of conventional and microfilled composites and a sealant are listed in Table 2. Weight loss per exposed surface area after $900 \mathrm{~h}$ of aging ranged from 0.46 to $1.16 \mathrm{mg} / \mathrm{cm}^{2}$ for the conventional composites and from 0.28 to $1.03 \mathrm{mg} / \mathrm{cm}^{2}$ for the microfilled composites and was $0.46 \mathrm{mg} / \mathrm{cm}^{2}$ for the sealant. Volume loss per exposed surface area was determined from the data of weight loss, density, and surface area. It ranged from 2.1 to $5.9 \times 10^{-3} \mathrm{~mm}^{3} / \mathrm{mm}^{2}$ for the conventional composites and from 2.0 to $7.3 \mathrm{x}$ $10^{-3} \mathrm{~mm}^{3} / \mathrm{mm}^{2}$ for the microfilled composites and was $3.9 \times 10^{-3} \mathrm{~mm}^{3} / \mathrm{mm}^{2}$ for the sealant. Values of Tukey's interval at the $95 \%$ level of confidence were 0.26 $\mathrm{mg} / \mathrm{cm}^{2}$ and $1.5 \times 10^{-3} \mathrm{~mm}^{3} / \mathrm{mm}^{2}$, respectively.
Scanning electron photomicrographs of the aged surfaces of the conventional composites and the microfilled composites and sealant are shown in Figs. 1 and 2, respectively. Crazing of the surface and exposure of filler particles were observed for the conventional composites. The surfaces of the microfilled composites also showed crazing. The surface of the sealant (D) appeared unchanged. The surfaces of all materials at baseline appeared smooth and without characteristic morphology, much like the surface of D in Fig. 2.

Infrared ATR spectra at zero and $900 \mathrm{~h}$ and difference spectra (zero minus $900 \mathrm{~h}$ ) of AR and SF are shown in Figs. 3 and 4, respectively. Changes in the spectra between zero and $900 \mathrm{~h}$ (Fig. 3) were observed for $\mathrm{AR}$ and were different from those observed for SF (Fig. 4).

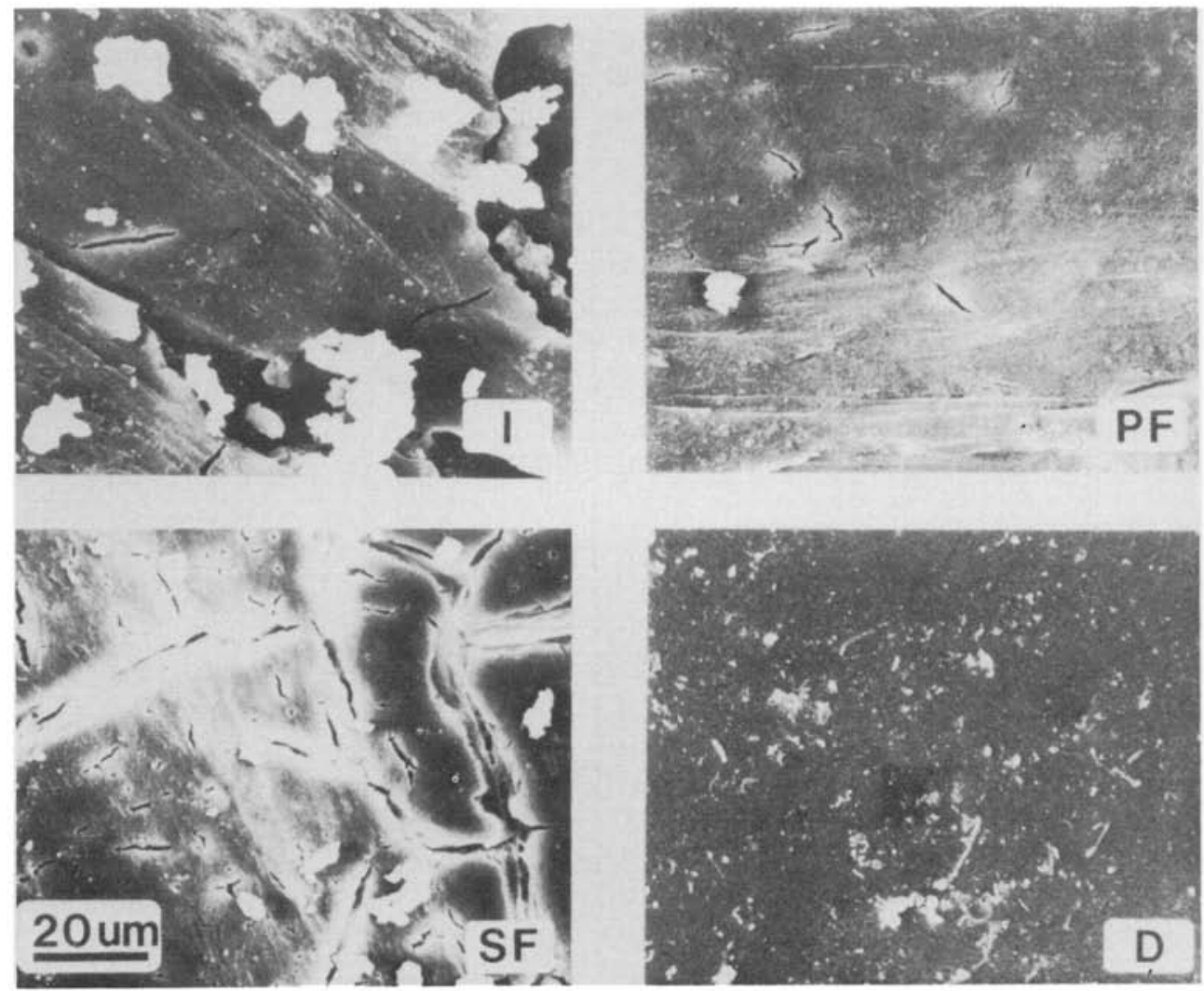

Fig. 2 - Scanning electron photomicrographs of aged surfaces of microfilled composites and a sealant (D). 


\section{Discussion.}

Similarities in the relative peak heights of spectra of AR and SF before and after aging confirm that loss of material from the surface by dissolution is occurring. Peaks observed at 1715 and $1170 \mathrm{~cm}^{-1}$ in the difference spectrum of AR (Fig. 3), however, are characteristic of an aliphatic carbonyl absorption. Changes in these peaks could be explained by photo-oxidation of the resin of $A R$. Conjugation resulting from condensed carbonyl compounds could explain changes in color reported for AR during accelerated aging. ${ }^{3}$ Clinically, photo-oxidation is an unlikely mechanism, but oxidation of the resin could occur in the presence of activated oxygen that might form chemically in the oral environment.

In vitro wear characteristics of commercial composites exposed to conditions of accelerated aging have been shown to differ from those of the unaged materials. ${ }^{4}$ Changes in wear track width, tangential force, and morphologies of surface failure caused by single-pass sliding were attributed to surface degradation. The weight loss data and preliminary FTIR-ATR spectra further support a hypothesis that changes in the surface chemistry of the composites occur during accelerated aging.

Comparisons of the weight loss and volume loss data (Table 2) do not suggest superiority of either the conventional or microfilled composites as a group, whereas two-body abrasion data ${ }^{5}$ demonstrate that conventional composites are more wear resistant in vitro. It is probable that wear of composites in vivo is affected by both mechanical and chemical mechanisms of degradation. For example, clinical data ${ }^{6}$ of composites $\mathrm{A}$ and $\mathrm{S}$ in Class 1 posterior restorations in humans suggest that initial wear results in loss of occlusal contact with opposing teeth and loss of margin integrity, with $\mathrm{S}$ changing more rapidly than $\mathrm{A}$. After $18 \mathrm{mo}$, however, no difference in loss of anatomic form can be detected between A and $S$. The present data suggest that the aging processes of $A$ and $S$ are similar, although A has been demonstrated to be superior to $\mathrm{S}$ in resistance to mechanical wear. ${ }^{7}$

Further research is necessary to more completely characterize the chemical degradation of composites that occurs as a

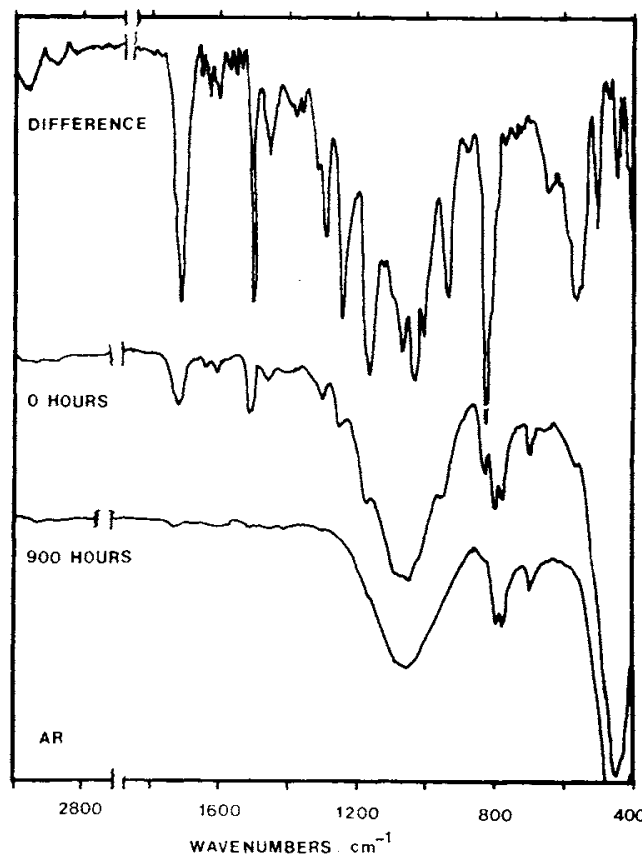

Fig. 3 - Infrared ATR spectra at zero and $900 \mathrm{~h}$ and difference spectrum (zero minus $900 \mathrm{~h}$ ) of AR.

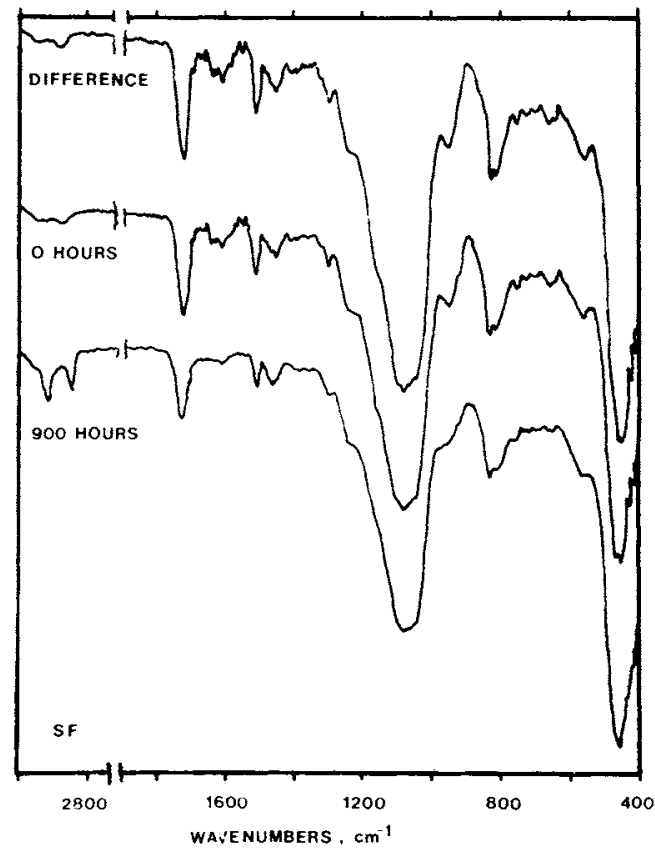

Fig. 4 - Infrared ATR spectra at zero and $900 \mathrm{~h}$ and difference spectrum (zero minus $900 \mathrm{~h}$ ) of SF. 
result of accelerated aging in vitro and that which may occur in vivo.

\section{Conclusions.}

The in vitro accelerated aging of conventional and microfilled composite restorative materials and a sealant was studied. Volume loss/surface area ranged from $2.0 \times 10^{-3}$ $\mathrm{mm}^{3} / \mathrm{mm}^{2}$ for I to $7.3 \times 10^{-3} \mathrm{~mm}^{3} / \mathrm{mm}^{2}$ for SF after $900 \mathrm{~h}$ of aging. Surface morphology of the conventional composites was characterized by crazing and exposure of filler particles. The surfaces of the microfilled composites also showed crazing. The surface morphology of the sealant appeared unchanged. Comparisons of infrared ATR spectra between zero and $900 \mathrm{~h}$ of aging showed that slight chemical changes occurred at the surface of AR but not SF.

\section{REFERENCES}

1. POWERS, J.M. and FAN, P.L.: Erosion of Composite Resins, J Dent Res 59:815-819, 1980 .
2. O'BRIEN, W.J. and YEE, J., Jr.: Microstructure of Posterior Restorations of Composite Resin After Clinical Wear, Operative Dentistry 5: 90-94, 1980.

3. POWERS, J.M.; DENNISON, J.B.; and KORAN, A.: Color Stability of Restorative Resins Under Accelerated Aging, $J$ Dent Res 57: 964-970, 1978.

4. FAN, P.L. and POWERS, J.M.: In vitro Wear of Aged Composite Restorative Materials, J Dent Res 59:2066-2070, 1980.

5. FAN, P.L.; POWERS, J.M.; and CRAIG, R.G.: In vitro Wear of Microfilled and Visible Lightcured Composites, $J$ Dent Res 58:2116-2119, 1979.

6. DENNISON, J.B.; POWERS, J.M.; and CHARBENEAU, G.T.: Measurement of in vivo Wear on Posterior Composite Restorations, AADR Progr \& Abst 59:No. 202, 1980.

7. ROOTARE, J.M.; POWERS, J.M.; and CRAIG, R.G.: Wear of Composites by Abrasives of Varying Hardness, $J$ Dent Res 58:1097-1100, 1979.

\section{MEETING ANNOUNCEMENT AND CALL FOR PAPERS}

The 39th Annual Meeting of the American Cleft Palate Association will be held at the Denver Hilton Hotel, Denver, Colorado, April 21-24, 1982. Requests for registration forms should be sent by non-members to:

$$
\begin{gathered}
\text { Mrs. Jane A. Graminski } \\
\text { Administrative Secretary } \\
331 \text { Salk Hall } \\
\text { University of Pittsburgh } \\
\text { Pittsburgh, PA } 15261
\end{gathered}
$$

The Program Committee is soliciting scientific papers, exhibits, films, and videotapes for presentation at the meeting. Entries should be submitted on official abstract forms which can be obtained from Mrs. Graminski.

The deadline for receipt of abstracts is October 15, 1981, and acceptances will be sent out in January, 1982. Abstracts should be sent to the Program Chairman:

$$
\begin{gathered}
\text { R.C.A. Weatherley-White, M.D. } \\
\text { Program Chairman } \\
155 \text { South Madison } \\
\text { Denver, Colorado } 80209
\end{gathered}
$$

